\title{
GROWTH PATTERNS AND HYDROGEN SULFIDE PRODUCTION BY MIXED CULTURES IN A CELLULOSE-BASED MICROCOSM
}

\author{
SIMON J. UTSALO ${ }^{1}$ AND S. MAIER ${ }^{2}$ \\ Department of Zoological and Biomedical Sciences, Ohio University, \\ Athens, Ohio, 45701, U.S.A.
}

(Received September 12, 1986)

\begin{abstract}
Studies of the trophic relationships in microbial reduction of sulfate established the need for three physiological types of organisms: cellulosedigesters (Cellulomonas, Cytophaga or Micromonospora), a lactic acid fermenter (Enterobacter), and a sulfate reducer (Desulfovibrio). Microcosms based on cellulose mineral salts medium were inoculated with varying combinations of mixed cultures and incubated at $30^{\circ} \mathrm{C}$ for 18 days. The extent of sulfate reduction varied in the microcosms. A 5member culture which contained the three cellulolytic organisms reduced the most sulfate $(52 \%)$. Cellulomonas was the most efficient cellulolytic partner. Unless all three physiological types were present, sulfate was not reduced.
\end{abstract}

In nature, the formation of sulfides through sulfate reduction is enhanced by low redox potential $(E h)$, availability of organic matter and a suitable temperature (1). When sulfate is reduced, the hydrogen sulfide $\left(\mathrm{H}_{2} \mathrm{~S}\right)$ evolved may combine with ferrous salts to form black sulfide deposits which appear in the profiles of boggy soils and aquatic muds. Sulfate-reducing bacteria may use organic substrates such as lactate $(2)$, choline and acetate $(3,4)$ as electron donors for sulfate reduction. In some strains, a reductive pathway through hydrogen oxidation has been observed $(5,6)$. Species of Desulfovibrio have limited substrate range so trophic interactions with other organisms is necessary to release nutrients from decomposing organic matter and to produce a reducing microenvironment for sulfate reduction. The degradation of plant detritus is through the activities of cellulolytic organisms. It is therefore clear that the generation and maintenance of various nutrient cycles in nature necessitate complex syntrophic relationships among microbial species. Tezuka et al. (7) in an ecological study of the Sumida River

1 Present Address: Department of Medical Microbiology and Parasitology, University of Calabar, Calabar, Nigeria.

2 Address reprint requests to: Dr. S. Maier, Department of Zoological and Biomedical Sciences, Ohio University, Athens, Ohio, 45701, U.S.A. 
Valley, noted that a carbohydrate-like substrate provided nutrients for bacterial sulfate reduction. TutTLE et al. (8) had similarly observed the roles of specialized microbial groups in the successive biotransformation pathways leading to sulfate reduction in acid mine water. In a subsequent study, TutTLE et al. (8) used laboratory models to evaluate trophic relationships in an acid mine ecosystem, with an undefined mixture of organisms as inoculum. To our knowledge, no studies on trophic interactions have used standardized microcosms with defined inoculum to evaluate the niche and response of each biotic component in a simulated ecosystem. This report defines the minimal number, the generic and physiological identity, and the responses of organisms that were required for necessary substrate transformations, starting with cellulose as the only organic substrate and culminating in the production of $\mathrm{H}_{2} \mathrm{~S}$ following sulfate reduction. Such relationships may be envisaged for natural ecosystems in which a mixture of specialized microbial groups create suitable microenvironments and release metabolites used as electron donors in the sulfate reduction pathway.

\section{MATERIALS AND METHODS}

Organisms. Three physiological types of organisms were used: cellulose digesters (Cellulomonas sp., Micromonospora sp. and Cytophaga sp.; designated C, $\mathrm{M}$, and $\mathrm{S}$ respectively), a lactic acid fermenter (Enterobacter cloacae, E), and a sulfate-reducer (Desulfovibrio desulfuricans, D). Cellulose-digesters were isolated from soil or aquatic muds, the lactic acid fermenter from aquatic habitats and the sulfate-reducer from aquatic mud.

Media for cellulolytic organisms. Except for Cytophaga sp. which was isolated according to WARKE and DHALA (9), other cellulose digesters were isolated after enrichment in the filter paper mineral broth (FMB) medium of Dubos (10), which was also used for their maintenance. A modification of the mineral medium (10), designated $\mathrm{CMB}$ and used for preparing microcosms contained $(\%, \mathrm{w} / \mathrm{v}): 0.025$, $\left(\mathrm{NH}_{4}\right)_{2} \mathrm{SO}_{4} ; 0.05, \mathrm{~K}_{2} \mathrm{HPO}_{4} ; 0.025, \mathrm{MgSO}_{4} \cdot 7 \mathrm{H}_{2} \mathrm{O} ; 0.005, \mathrm{CaCl}_{2} \cdot 5 \mathrm{H}_{2} \mathrm{O} ; 0.01$, $\mathrm{FeSO}_{4} \cdot 7 \mathrm{H}_{2} \mathrm{O} ; 1.0$, Microcrystalline Cellulose (Sigma Cell Type 20, Sigma Chemical Co., St. Louis, Mo.), pH 7.2. Cellulolytic colonies were purified on CMA streak plates consisting of CMB medium and agar $(1 \%)$. Viable counts were on CMA pour plates prepared with $3 \mathrm{ml}$ of inoculated CMA soft agar $(0.7 \%)$ overlaid on CMA base.

Media for lactic acid fermenter. E. cloacae was purified on cellobiose mineral agar (CbMA) prepared from mineral medium (10) and supplemented with yeast extract $(1 \%), \mathrm{D}(+)$-cellobiose $(1 \%)$ (Sigma Chemical Co., St. Louis, Mo.) and solidified with agar $(1 \%)$. Viable counts of $\mathrm{E}$ were done on sucrose bromothymolblue agar (SBA) spread plates consisting of mineral medium (10), supplemented with sucrose $(1 \%)$, bromothymol blue $(0.003 \%)$, yeast extract $(1 \%)$ and agr $(1 \%)$.

Media for sulfate-reducer. The two media used, MBC and MBA, were modifications of medium $\mathrm{C}$ of BuTLIN et al. (11). MBC used for the isolation and 
maintenance of $\mathrm{D}$ contained $(\%, \mathrm{w} / \mathrm{v}): 0.05, \quad \mathrm{~K}_{2} \mathrm{HPO}_{4} ; 0.1, \quad \mathrm{NH}_{4} \mathrm{Cl} ; 0.1$, $\mathrm{CaCl}_{2} \cdot 2 \mathrm{H}_{2} \mathrm{O} ; 0.2, \mathrm{MgSO}_{4} \cdot 7 \mathrm{H}_{2} \mathrm{O} ; 0.1, \mathrm{Na}_{2} \mathrm{SO}_{4} ; 0.35$, lithium lactate; 0.1 , yeast extract; 0.02 , ascorbic acid; $0.001, \mathrm{FeSO}_{4} \cdot 7 \mathrm{H}_{2} \mathrm{O}(\mathrm{pH}$ 7.6). Cultures were maintained at $4{ }^{\circ} \mathrm{C}$ with weekly sub-cultures. The viable count of $\mathrm{D}$ was by the three-tube Most Probable Number (MPN) method (12), using MBA deep tubes prepared from MBC medium solidified with agar $(1 \%)$.

Microcosms. The microcosms consisted of $7 \mathrm{ml}$ of CMB in screw cap tubes $(150 \times 16 \mathrm{~mm})$. For inoculation, cultures grown individually in maintenance broths were diluted in sterile distilled water and pooled to prepare a mixed inoculum. Microcosms were inoculated with $0.1 \mathrm{ml}$ of composite inoculum to give the following final concentrations; Strain C, $5.2 \times 10^{4} / \mathrm{ml}$ or $1.3 \times 10^{5} / \mathrm{ml} ; \mathrm{S}, 4.1 \times 10^{3} /$ $\mathrm{ml} ; \mathrm{M}, 1.6 \times 10^{3} / \mathrm{ml}$ E, $6.4 \times 10^{3} / \mathrm{ml}$ and $\mathrm{D}$ at $6.4 \times 10^{2} / \mathrm{ml}$ or $5.3 \times 10^{3} / \mathrm{ml}$. Variations of mixed inocula were used in different microcosms and designated as TXB (consisting of C, S, M, E, and D); CXB (C, E, and D), SXB (S, E, and D), MXB (M, E, and D). Control microcosms were solitary cultures and various combinations of 2-member cultures. Lead acetate-impregnated filter paper strips suspended in microcosm tubes were retained with loosened screw caps. All incubations were stationary in air at $30^{\circ} \mathrm{C}$ for 18 days. Analyses of replicate tubes were done at 3-day intervals thereafter.

Analyses. Viable organisms (C, S, M, E, and D) from microcosms were counted with the media as already described. Serial dilutions of D, were prepared with $0.1 \mathrm{M}$ phosphate buffer ( $\mathrm{pH} 7.3$ ) containing $0.02 \%$ ascorbic acid. Lactic acid produced by $\mathrm{E}$ in stationary $\mathrm{CbMB}$ was determined according to BARKER and Summerson (13).

Soluble carbohydrate was determined by the phenol-sulfuric acid method (14) after filtration $(0.45 \mu \mathrm{m}$ filter, Millipore Corp., Bedford, Mass.) of mixed replicate microcosm tubes. Products of cellulose hydrolysis by $\mathrm{C}, \mathrm{S}$, and $\mathrm{M}$ in $\mathrm{CMB}$ were identified by thin layer chromatography (Chromatogram Type 6061, Eastman Kodak Co., Rochester, N.Y.) in isopropanol : butanol : water $(140: 40: 20)$ solvent. A methanol:chloroform $(1: 1)$ extract of the culture filtrate $(10 \mu 1)$ was spotted. Plates dipped in aniline $(1 \%)$, diphenylamine $(1 \%)$, acetone : $85 \%$ phosphoric acid $(10: 1)$ were heated at $100^{\circ} \mathrm{C}$ for $10 \mathrm{~min} . \mathrm{D}(+)$-Glucose and $\mathrm{D}(+)$-cellobiose were used as controls. Sulfate concentrations were determined by the turbidimetric method (Hach Chemicals Co., Loveland, CO.). The amount of $\mathrm{H}_{2} \mathrm{~S}$ produced in each microcosm was estimated semi-quantitatively (on a 4-point scale) by visual assessment of sulfide precipitate and the blackness of lead acetate papers.

\section{RESULTS}

\section{Characterization of isolates}

Identification of organisms and characteristics important for this investigation are given in Table 1. Strain C, Cellulomonas sp. was identified according to Bergey's Manual(15). S was a Cytophaga sp. identified according to Bergey's Manual(15) 
Table 1. A summary of the characteristics of the isolates.

\begin{tabular}{|c|c|c|c|c|c|c|}
\hline Strain & Identification & $\begin{array}{l}\text { Identification } \\
\text { reference }\end{array}$ & Source & $\begin{array}{l}\text { Relationship } \\
\text { to oxygen }\end{array}$ & $\begin{array}{l}\text { Metabolic } \\
\text { activity }\end{array}$ & $\begin{array}{l}\text { Substrate } \\
\text { transformation }\end{array}$ \\
\hline $\mathrm{C}$ & Cellulomonas sp. & 15 & Soil & $\begin{array}{r}\text { Facultative } \\
\text { anaerobe }\end{array}$ & $\begin{array}{l}\text { Cellulose } \\
\text { digestion }\end{array}$ & $\begin{array}{l}\text { Cellulose to } \\
\text { cellobiose }\end{array}$ \\
\hline $\mathrm{S}$ & Cytophaga sp. & 15,16 & Soil & $\begin{array}{r}\text { Facultative } \\
\text { anaerobe }\end{array}$ & $\begin{array}{l}\text { Cellulose } \\
\text { digestion }\end{array}$ & $\begin{array}{l}\text { Cellulose to } \\
\text { glucose }\end{array}$ \\
\hline $\mathbf{M}$ & $\begin{array}{l}\text { Micromonospora } \\
\quad \text { sp. }\end{array}$ & 17 & $\begin{array}{l}\text { Aquatic } \\
\text { mud }\end{array}$ & Aerobe & $\begin{array}{l}\text { Cellulose } \\
\text { digestion }\end{array}$ & $\begin{array}{l}\text { Cellulose to } \\
\text { glucose }\end{array}$ \\
\hline $\mathrm{E}$ & $\begin{array}{l}\text { Enterobacter } \\
\text { cloacae }\end{array}$ & 15 & $\begin{array}{l}\text { Aquatic } \\
\text { habitat }\end{array}$ & $\begin{array}{r}\text { Facultative } \\
\text { anaerobe }\end{array}$ & $\begin{array}{l}\text { Lactic acid } \\
\text { fermenta- } \\
\text { tion }\end{array}$ & $\begin{array}{l}\text { Cellobiose/glucose } \\
\text { to lactic acid }\end{array}$ \\
\hline $\mathrm{D}$ & $\begin{array}{l}\text { Desulfovibrio } \\
\quad \text { desulfuricans }\end{array}$ & 18 & $\begin{array}{l}\text { Aquatic } \\
\text { mud }\end{array}$ & $\begin{array}{l}\text { Obligate } \\
\text { anaerobe }\end{array}$ & $\begin{array}{l}\text { Sulfate } \\
\text { reduction }\end{array}$ & $\begin{array}{l}\text { Lactate to acetate, } \\
\text { sulfate to sulfide } \\
\left(\mathrm{H}_{2} \mathrm{~S}\right)\end{array}$ \\
\hline
\end{tabular}

Table 2. Production of $\mathrm{H}_{2} \mathrm{~S}$ in microcrystalline culture medium by pure cultures and various mixtures of organisms.

\begin{tabular}{|c|c|c|c|c|c|c|c|c|c|c|c|c|c|c|c|c|}
\hline \multirow{2}{*}{ Organisms } & \multirow{2}{*}{ Strain } & \multicolumn{11}{|c|}{ Control cultures } & \multicolumn{4}{|c|}{ Test cultures } \\
\hline & & 1 & 2 & 3 & 4 & 5 & 6 & 7 & 8 & 9 & 10 & 11 & 12 & 13 & 14 & 15 \\
\hline Cellulomonas & $\mathrm{S}$ & $\mathrm{S}$ & $\mathrm{O}$ & $\mathrm{O}$ & $\mathrm{O}$ & $\mathrm{O}$ & $\mathrm{S}$ & $\mathrm{S}$ & $\mathrm{O}$ & $\mathrm{O}$ & $\mathrm{O}$ & $\mathrm{O}$ & $\mathrm{S}$ & $\mathrm{S}$ & $\mathrm{O}$ & $\mathrm{O}$ \\
\hline Cytophaga & $\mathrm{C}$ & $\mathrm{O}^{a}$ & $\mathrm{C}$ & $\mathrm{O}$ & $\mathrm{O}$ & $\mathrm{O}$ & $\mathrm{O}$ & $\mathrm{O}$ & $\mathrm{C}$ & $\mathrm{C}$ & $\mathrm{O}$ & $\mathrm{O}$ & $\mathrm{C}$ & $\mathrm{O}$ & $\mathrm{C}$ & $\mathrm{O}$ \\
\hline Micromonospora & M & $\mathrm{O}$ & $\mathrm{O}$ & M & $\mathrm{O}$ & $\mathrm{O}$ & $\mathrm{O}$ & $\mathrm{O}$ & $\mathrm{O}$ & $\mathrm{O}$ & M & M & M & $\mathrm{O}$ & $\mathrm{O}$ & M \\
\hline Enterobacter & $\mathrm{E}$ & $\mathrm{O}$ & $\mathrm{O}$ & $\mathrm{O}$ & $\mathrm{E}$ & $\mathrm{O}$ & $\mathrm{E}$ & $\mathrm{O}$ & $\mathrm{E}$ & $\mathrm{O}$ & $\mathrm{E}$ & $\mathrm{O}$ & $\mathrm{E}$ & $\mathrm{E}$ & $\mathrm{E}$ & $\mathrm{E}$ \\
\hline Desulfovibrio & $\mathrm{D}$ & $\mathrm{O}$ & $\mathrm{O}$ & $\mathrm{O}$ & $\mathrm{O}$ & D & $\mathrm{O}$ & $\mathrm{D}$ & $\mathrm{O}$ & $\mathrm{D}$ & $\mathrm{O}$ & $\mathrm{D}$ & $\mathrm{D}$ & $\mathrm{D}$ & $\mathrm{D}$ & $\mathrm{D}$ \\
\hline $\mathrm{H}_{2} \mathrm{~S}$ production & & - & - & - & - & - & - & - & - & - & - & - & + & + & + & + \\
\hline
\end{tabular}

${ }^{a} \mathrm{O}=$ Organisms not present in culture.

and Stanier (16). M, an actinomycete, was identified as Micromonospora sp. (17). E was identified as Enterobacter cloacae $(15)$. Lactic acid $(125 \mu \mathrm{g} / \mathrm{ml})$ was detected in 24 stationary CbMB cultures of E (data not shown). D was identified as Desulfovibrio desulfuricans (18).

\section{Detection of $\mathrm{H}_{2} \mathrm{~S}$ production in mixed cultures}

Table 2 shows the pattern of $\mathrm{H}_{2} \mathrm{~S}$ production by mixed cultures. No hydrogen sulfide was produced either by solitary cultures (rows 1-5) or by any 2-member cultures (rows 6-11). Only 5-member (rows 12) and 3-member cultures (rows 13-15) produced $\mathrm{H}_{2} \mathrm{~S}$. 


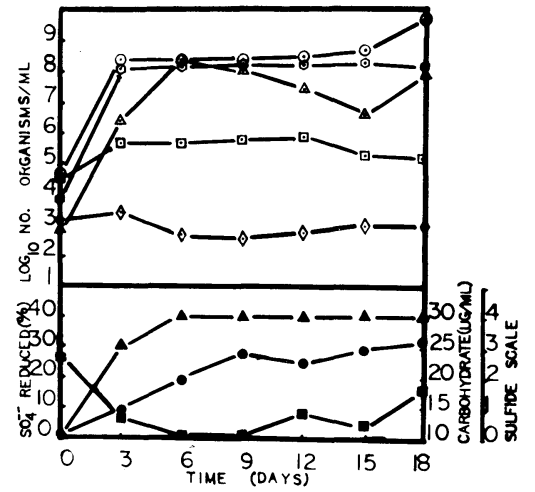

Fig. 1. Growth of mixed cultures of Cellulomonas $\odot$, Cytophaga $\square$, Micromonospora $\diamond$, Enterobacter $\bigcirc$, and Desulfovibrio $\triangle$, and changes in the concentrations of sulfate $\bullet$, soluble carbohydrate $\mathbf{a}$, and sulfide $^{1} \boldsymbol{\Delta}$ in TXB.

1 Sulfide grade schale:

$4+=$ cellulose precipitate completely black, $\geq 15 \mathrm{~mm}$ of lead acetate paper black.

$3+=$ cellulose precipitate partly black, $>10-15 \mathrm{~mm}$ of lead acetate paper black.

$2+=$ cellulose precipitate white, $>6-10 \mathrm{~mm}$ of lead acetate paper black.

$1+=$ cellulose precipitate white, $>1-5 \mathrm{~mm}$ of lead acetate paper black.

$0=$ cellulose precipitate white, lead aceate paper white.

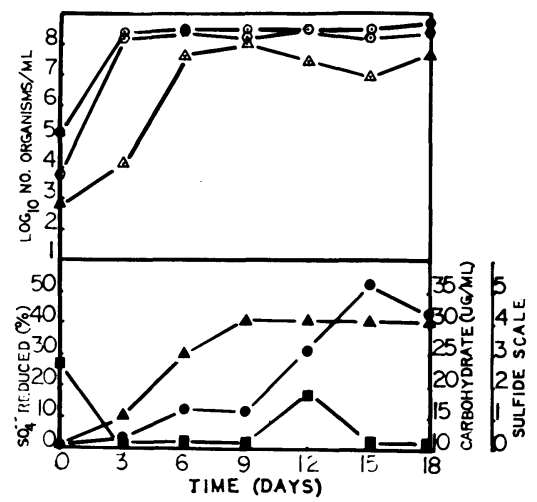

Fig. 2. Growth of mixed cultures of Cellulomonas $\bigcirc$, Enterobacter $\bigcirc$, and Desulfovibrio $\triangle$, and changes in the concentration of sulfate $\bullet$, soluble carbohydrate and sulfide $\Delta$ in $\mathrm{CXB}$.

\section{Growth of mixed populations}

Microbial growth patterns in the microcosms are shown in Figs. 1-4. Of the 3 cellulose digesters in TXB, Cellulomonas grew the most in contrast with the growth suppression of Cytophaga and Micromonospora. In CXB (Fig. 2), the only cellulolytic partner was Cellulomonas. Growth increases of this organism in TXB and CXB were comparable (Figs. 1 and 2). Cytophaga was the only cellulose 


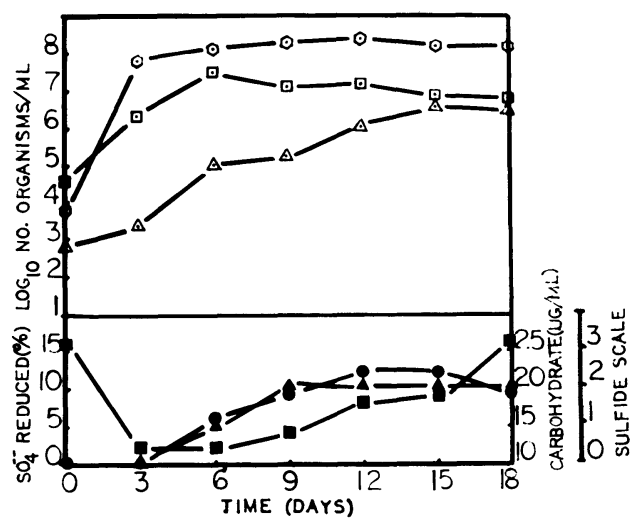

Fig. 3. Growth of Cytophaga $\square$, Enterobacter $\bigcirc$, and Desulfovibrio $\triangle$, and changes in the concentration of sulfate $\bullet$, soluble carbohydrate $\mathbf{\square}$, and sulfide $\boldsymbol{\Delta}$ in SXB.

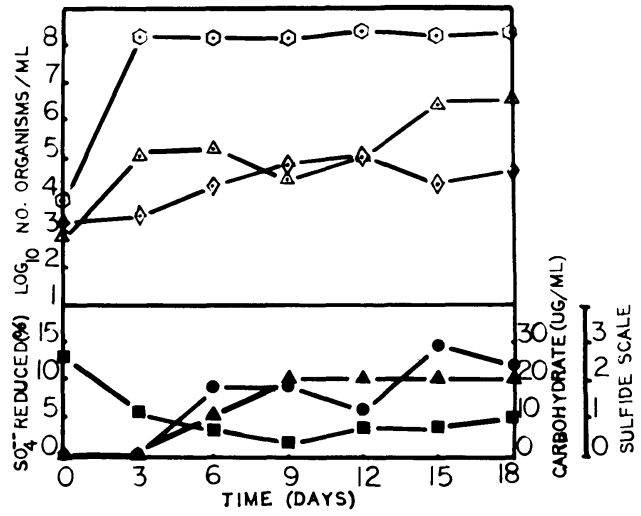

Fig. 4. Growth of Micromonospora $\diamond$, Enterobacter $\bigcirc$, Desulfovibrio $\triangle$, and changes in the concentration of sulfate $\bullet$, soluble carbohydrate $\mathbf{a}$, and sulfide in MXB.

digester in SXB (Fig. 3) where its growth was more than that detected in TXB. In MXB (Fig. 4), the increases in the Micromonospora population, the only cellulolytic partner, were marginal, but represented more growth relative to its suppression in the 5-member TXB system. Growths in the order of 4-log increases by day 3 were characteristic of E. cloacae in all microcosms (Figs. 1-4). For Desulfovibrio, growth in TXB and CXB (Figs. 1 and 2) were remarkable, similar and generally more than it was in SXB and MXB (Figs. 2 and 4).

Changes in soluble carbohydrates, sulfate concentration and sulfide production

Figures 1-4 show the changes in the concentration of soluble carbohydrates, sulfates, and the amount of sulfides. Except for Cellulomonas which produced cellobiose, all of the organisms produced glucose by cellulose hydrolysis (Table 1). 
In all microcosms, there was an initial concentration of glucose of $26 \mu \mathrm{g} / \mathrm{ml}$. During incubation, changes in the concentration of the soluble carbohydrate varied in each microcosm (Figs. 1-4).

Of the $650 \mu \mathrm{g}$ of sulfate initially present in the microcosms, the highest reductions of 32 and $52 \%$ occurred in TXB and CXB respectively (Figs. 1-2), where there was marked blackness of cellulose precipitate and lead acetate papers. Less reductions $(15 \%)$ in SXB and MXB were only manifested as blackness of lead acetate papers (Figs. 3 and 4).

\section{DISCUSSION}

Repeated attempts to isolate anaerobic cellulose digesters from aquatic muds were unsuccessful (unpublished data). For aerobic cellulose digesters we have shown that their metabolic products could not serve as electron donors for Desulfovibrio (Table 2, cultures 7, 9, 11). These organisms produced mono- and disaccharides (Table 1). Therefore an organism able to ferment these saccharides to lactic acid was needed. E. cloacae fulfilled this requirement (Table 1). Tested on this trophic relationship, sulfate reduction by Desulfovibrio became possible (Table 2, cultures 12-15). Sulfide production was not improved by the simultaneous presence of three different cellulose digesters (Fig. 1), as compared to only Cellulomonas (Fig. 2). Therefore the simultaneous presence of one representative of each of the three physiological types (cellulose digester, fermenter, sulfate reducer) is the sufficient and necessary condition for $\mathrm{H}_{2} \mathrm{~S}$ production from cellulose in mineral media. The marked growth of Cellulomonas in TXB and CXB contrasted with the reduced growth of Cytophaga and Micromonospora in TXB. But Cytophaga and Micromonospora were not inhibited in SXB and MXB respectively. The importance of nutritional adaptation and sulfide tolerance on growth quality in these microcosms is not clear. The toxicity of $\mathrm{H}_{2} \mathrm{~S}$ for microorganisms is well known $(1,2,19,20)$. Presumably $\mathrm{H}_{2} \mathrm{~S}$ toxicity (and or lack of oxygen) was a factor in the suppression of growths of Cytophaga and Micromonospora in TXB. Adaptation to competition for nutrients in an oxygen gradient can determine the quality of submerged growth, especially on an insoluble substrate such as cellulose which has a tactile influence on cellulolytic organisms. However, we were cautious in the interpretation of growth of Micromonospora since, as a mycelial organism, its growth may not be assessed reliably by colony counts which rely on the changes in the numbers of individual cells. The growth of Desulfovibrio and the sulfate reduction which occurred only in 5-member and 3-member systems suggested that suitable reducing micro-environments prevailed in these microcosms. The redox potential of -140 to $-120 \mathrm{mV}$ are the observed optima for Desulfovibrio $(10,21)$. We did not determine changes in $E h$ and $\mathrm{pH}$ values in our microcosms. However observations from preliminary studies on microcosms incorporating resazurin indicated active reduction of sulfate below fluid columns of high oxygen tension.

We cannot explain why $12 \%$ sulfate reductions in SXB and $15 \%$ in MXB 
manifested themselves only as blackness of lead acetate papers $(2+)$ while similar or lesser reductions in TXB and $\mathrm{CXB}$ were marked by blackness of both cellulose precipitate and lead acetate papers $(3+, 4+$ respectively). It is possible for such discrepancy to be due to error inherent in the subjective method used for sulfide assessment. Furthermore, it seems clear that the non-dissimilatory loss of sulfate in SXB and MXB may be due to the small amounts assimilated by organisms for biosynthesis. The increases in Desulfovibrio populations in SXB and MXB with low overall reduction of sulfate cannot be explained from this study.

Very interesting was the stability achieved with the 3-member cultures which appeared to be such that other bacterial species such as the methanogenic bacteria which require acetate or Beggiatoa which uses $\mathrm{H}_{2} \mathrm{~S}$ and acetate for mixotrophic metabolism may be introduced into these co-cultures. The system reported in this study has been found to support mixotrophic growth of Beggiatoa in co-culture (Utsalo and Maier, unpublished data). It is therefore a refinement of the enrichment of FAUST and WOLFE (22) for Beggiatoa cultures and has the advantage of standardized inocula and growth conditions.

\section{REFERENCES}

1) M. Alexander, In Introduction to Soil Microbiology, ed. by M. Alexander, John Wiley \& Sons, New York (1977), p. 363.

2) Th. E. Cappenberg, Antonie van Leeuwenhoek; J. Microbiol. Serol., 40, 457 (1974).

3) M. T. Balba and D. B. Nedwell, J. Gen. Microbiol., 128, 1215 (1982).

4) M. R. Winfrey and D. M. Ward, Appl. Environ. Microbiol., 45, 193 (1983).

5) I. M. Banat, E. B. Lindstrom, D. B. Nedwell, and M. T. Balba, Appl. Environ. Microbiol., 42, 985 (1981).

6) D. R. Lovely and M. J. Klug, Appl. Environ. Microbiol., 45, 187 (1983).

7) Y. Tezuka, S. TakiI, and H. Kitamura, Jpn. J. Ecol., 13, 188 (1963).

$8)$ J. H. Tuttle, P. R. Dugan, C. B. Macmillan, and C. I. Randles, J. Bacteriol, 97, 595 (1969).

9) G. M. Warke and S. D. Dhala, J. Gen. Microbiol., 51, 43 (1968).

10) R. J. Dubos, J. Bacteriol., 15, 223 (1928).

11) K. R. Butlin, M. E. Adams, and M. Thomas, J. Gen. Microbiol., 3, 46 (1949).

12) Standard Methods for the Examination of Water and Waste Water, ed. by American Public Health Association, Inc., Washington, D. C. (1975).

13) S. B. Barker and W. H. Summerson, J. Biol. Chem., 138, 535 (1941).

14) M. Dubois, K. A. Gilles, C. R. Hamilton, R. A. Rebers, and F. Smith, J. Anal. Chem., 28, 350 (1956).

15) R. E. Buchanan and N. E. Gibbons, In Bergey's Manual of Determinative Bacteriology, 8th ed., ed. by R. E. Buchanan and N. E. Gibbons, The Williams and Wilkins Co., Baltimore (1974).

16) R. Y. STANIER, Bacteriol. Rev., 6, 143 (1942).

17) G. SyKeS and F. A. Skinner, In Actinomycetes: Characterization and Practical Importance, ed. by the Society for Applied Bacteriology, Symposium Series No. 2, Academic Press, London (1973).

18) J. R. Postgate and L. L. Campbell, Bacteriol. Rev., 30, 732 (1966).

19) T. D. Brock and K. O'Dea, Appl. Environ. Microbiol., 33, 254 (1977).

20) T. E. CAPpenberg, Microbiol. Ecol., 2, 60 (1975).

21) J. R. Postgate, Bacteriol. Rev., 29, 425 (1965).

22) L. Faust and R. S. Wolfe, J. Bacteriol., 81, 99 (1961). 